\title{
Yabancı Plakalı Motorlu Kara Taşıtlarının Karıştıkları Kazalardan Dolayı Yeşil Kart Sigortası Kapsamında Türkiye Motorlu Taşıt
} Bürosuna Dava Açılması

\author{
Musa Aygül* ${ }^{*}$
}

Öz

Türkiye'ye giriş yapmak isteyen yabancı plakalı araçların işletenleri, mevzuat gereği ya sınır kapılarında zorunlu malî sorumluluk sigortası (ZMSS) yaptırmak zorundadır ya da Türkiye'de geçerli Yeşil Kart Sigortasına sahip olmalıdır. Yeşil Kart Sistemi, motorlu kara taşıtlarının milletlerarası hareketliliğini kolaylaştırmak ve yabancı plakalı araçların işletilmesi esnasında verdikleri zararların, kazanın meydana geldiği ülkede ZMSS limitleri ve şartları dâhilinde tazmini sağlamak amacıyla oluşturulmuştur. Türkiye'de Yeşil Kart Sigortası işlemlerini yerine getirmek amacıyla Türkiye Motorlu Taşıtlar Bürosu (TMTB) kurulmuştur. Yeşil Kartlı yabancı plakalı bir aracın Türkiye'de karıştı̆̆ bir trafik kazasından dolayı başkalarının uğradığı zararın tazmini, yabancı sigorta şirketi ya da büro adına TMTB tarafindan gerçekleştirilmektedir. Zarar görenler Yeşil Kart düzenleyen yabancı sigorta şirketi ya da ilgili büro yerine doğrudan TMTB'ye müracaat edebilmekte ya da dava açabilmektedir. Bu çalışmada, zarar görenler karşısında TMTB'nin sorumluluğunun hukukî dayanakları ve davadaki konumu üzerinde durulmuştur. Türkiye'de görülmekte olan davalarda TMTB'nin yabancı sigorta ya da ilgili büroya yöneltilen davaların hukuki dayanağı incelenmiştir.

\section{Anahtar Kelimeler}

Yeşil Kart Sigortası, Türkiye Motorlu Taşıt Bürosu, Yabancı plakalı araçların Türkiye'de kaza yapması, Türkiye Motorlu Taşıt Bürosunun zarar görenlerin açttkları davadaki konumu, Yeşil Kart Sistemi

Filling a Law Suit Against the Turkish Motor Insurers' Bureau based on Green Card Insurance, due to the Accidents Caused by Vehicles with Foreign Licence Plates

\begin{abstract}
Vehicles with foreign license plates can only be accepted in Turkey if they are insured with compulsory automobile liability insurance at the border gate or with Green Card Insurance valid for Turkey as required by regulations. The Green Card System was established to facilitate the international mobility of motor land vehicles and to ensure the compensation of damages borne by third parties because of an accident caused by vehicles with foreign license plates; however, this is subject to the limitations and conditions of the mandatory liability insurance in the country where the accident occurred. The Turkish Motor Insurers' Bureau (TMIB) executes and oversees Green Card Insurance operations in Turkey. In traffic accidents involving vehicles with foreign license plates with a Green Card, damages borne by third parties are compensated by the TMIB on behalf of foreign insurance companies or offices. Victims can directly apply to the TMIB instead of filing a lawsuit against foreign insurance companies or the office that issued the Green Card. The study elucidates the legal basis of the liability and particularly analyzes the legal status of the TMIB against victims.
\end{abstract}

\section{Keywords}

Green Card Insurance, Turkish Motor Insurers' Bureau, Traffic accidents involving vehicles with foreign licenses plates in Turkey, Legal status of the Turkish Motor Insurers' Bureau against victims in a case, Green Card System

* Sorumlu Yazar: Musa Aygül (Doç. Dr.), Ankara Yıldırım Beyazıt Üniversitesi, Hukuk Fakültesi, Milletlerarası Özel Hukuk Anabilim Dalı, Ankara, Türkiye. E-posta: musaaygul1@gmail.com ORCID: 0000-0003-0363-9101

Atıf: Aygul M, "Yabancı Plakalı Motorlu Kara Taşıtlarının Karıştıkları Kazalardan Dolayı Yeşil Kart Sigortası Kapsamında Türkiye Motorlu Taşıt Bürosuna Dava Açılması" (2021) 79(2) İstanbul Hukuk Mecmuası 519. https://doi.org/10.26650/mecmua.2021.79.2.0006 


\section{Extended Summary}

Vehicles having foreign license plates can enter Turkey with several requirements. According to applicable legislation, all vehicles having foreign license plates shall be accepted in Turkey if they are insured with obligatory automobile liability insurance at the border gate or with Green Card Insurance valid for Turkey.

Article 91/5 of Highway Traffic Law regulates that compulsory automobile liability insurance must be done at the border gate under circumstances determined by Undersecretariat of Treasury for vehicles, providing that vehicles having foreign license plates have no valid insurance in Turkey.

Obligatory automobile liability insurance taken in Turkey is only valid within the borders of the Turkish Republic. Taking out an insurance abroad is also possible. However, specific provisions are in place for taking out an insurance that is valid outside the country. For example, Article 14 of the Turkish Insurance Law specifies the requirements of insurance taken outside the country. Therefore, for the insurance to be valid outside the country, either separate insurance must be taken in that state or valid insurance contracts should be present for usage in the country as well as abroad.

After World War II, not only international trade but also international tourism has prospered. Thus, the use of motor land vehicles between European countries has increased too. Hence, the Working Party on Road Transport of the Inland Transport Committee of the Economic Commission for Europe of the United Nations was established to diminish the problems. The Committee drawn up Recommendation No. 5, in which the basis of the Green Card System was founded. With such recommendation, the working group recommended to the governments of the member states to establish uniform and easily enforceable policies to ensure that drivers will be satisfactorily insured upon entering countries where drivers must have insurance. Alternatively, in the recommendation, member states agreed to establish a central organization under the name "bureau" to ensure the operation of such insurance system in each member state.

The Green Card System aims to facilitate the passage of motor land vehicles across international borders with an internationally valid insurance certificate and protect victims of accidents that involve vehicles with foreign license plates in the country where they are traveling to.

In 1959, the European Convention on Compulsory Financial Liability Insurance for Motor Vehicles was prepared and opened for signature by the Council of Europe. The contract entered into force in September 22, 1969. The Convention was signed, with some reservations, in 1974 and confirmed in 1999 by Law No. 4477. Thus, as stipulated in the Convention, Turkish Motor Insurers' Bureau (TMIB) has been 
founded to exercise Green Card Insurance operations in Turkey. Damages borne by third parties are compensated by the TMIB on behalf of foreign insurance companies or offices in cases of traffic accidents involving vehicles with foreign license plates with a Green Card. Victims can directly apply to the TMIB instead of filing a lawsuit against foreign insurance companies or the office that issued the Green Card.

The article examines the legal basis of the liability and particularly analyzes the legal status of the TMIB against victims within the scope of the paper. The article indicates which law applies to dispute in accidents involving vehicles with foreign license plates and specifies the role of the mandatory rules in applicable law. 


\section{Giriş}

Türkiye'ye giriş yapmak isteyen yabancı plakalı araçların işletenleri, mevzuat gereği ya sınır kapılarında zorunlu malî sorumluluk sigortası (ZMSS) yaptırmak; ya da Türkiye'de geçerli Yeşil Kart Sigortasına sahip olmak zorundadır. Yeşil Kart Sistemi, motorlu kara taşıtlarının milletlerarası hareketliliğini kolaylaştırmak ve yabancı plakalı araçların sebebiyet verdiği zararların, kazanın meydana geldiği ülkede zorunlu mesuliyet sorumluluk sigortası limitleri ve şartları dâhilinde karşılanmasını sağlamak amaciyla oluşturulmuştur. Türkiye'de de söz konusu Yeşil Kart Sigortası işlemlerini yerine getirmek ve yabancı plakalı araçların karıştığ görenlerin daha etkili bir şekilde korunmasını temin amacıyla Türkiye Motorlu Taşitlar Bürosu (TMTB) kurulmuştur.

Yeşil Kartlı yabancı plakalı bir aracın Türkiye'de karıştığı bir trafik kazasından dolayı üçüncü kişilerin uğradığı zararın tazmini, yabancı sigorta şirketi ya da büro adına TMTB tarafından gerçekleştirilmektedir. Zarar görenler Yeşil Kartı düzenleyen yabanc1 sigorta şirketi ya da ilgili büro yerine doğrudan TMTB'ye müracaat edebilmekte ya da dava açabilmektedir. Bu çalışmada, zarar görenler karşısında TMTB'nin sorumluluğunun hukukî dayanakları ve davadaki konumu üzerinde durulacaktır. Türkiye' de görülmekte olan davalarda TMTB ya da yabancı sigorta şirketine yöneltilen davaların hukukî dayanağı incelenecektir. Buna ek olarak zarar görenlerin açtığı davada görevli mahkeme ve bu uyuşmazlıklar için uygulanacak hukukun tayininde esas alınması icap eden kıstaslar, konuya ilişkin Yargıtay kararları 1şı̆̆ında izah edilecektir.

\section{Yeşil Kart Sigortası Sisteminin İşleyişi}

Yabancı plakalı araçlar belirli koşullar altında Türkiye'ye giriş yapabilmektedir. Örneğin Türkiye'ye turistik amaçlarla gelen yabancılar ya da yurt dışında çalışan Türk vatandaşları, özellikle yaz aylarında kendilerine ait ya da kiraladıkları motorlu kara taşıtları ile Türkiye'ye gelmektedir. Yine yurt dışında yerleşik kişiler ${ }^{1}$ tarafından yabancı plakalı araçlar geçici ithalat kapsamında yahut transit geçiş yapmak üzere Türkiye’ye getirilebilir².

2918 sayılı Karayolları Trafik Kanunu'na ${ }^{3}$ (KTK) göre yabancı plakalı taşıtların Hazine Müsteşarlığının bağlı olduğu Bakanlıkça belirlenecek usul ve esaslara göre

4458 Sayılı Gümrük Kanunu'nun Bazı Maddelerinin Uygulanması Hakkında 2009/15481 Sayılı Bakanlar Kurulu Kararında, Türkiye Gümrük Bölgesi dışında yerleşik kişi, olağan durumda Türkiye Gümrük Bölgesi dışında ikamet eden gerçek kişi ya da Türkiye Gümrük Bölgesi dışında kayıtlı işyeri bulunan tüzel kişi olarak tanımlanmıştır (m 3/v). Karar için bkz RG 7.10.2009/27369.

2 Türkiye, geçici ithalata ilişkin Geçici İthalat Sözleşmesini kabul etmiştir. Sözleşme için bkz RG 21.10.2004/25620. Sözleşmede geçici ithalat, belirli eşyanın (taşıma araçları dâhil) gümrük vergileri ve ithalatta alınan diğer vergilerin ödenmesinden şartlı olarak vazgeçilerek ve ekonomik nitelikli ithalat yasakları veya kısıtlamaları uygulanmaksızın, gümrük hattına girmesini sağlayan gümrük rejim olarak tanımlanmıștır $(\mathrm{m} \mathrm{1)}$. Kara taşıtlarının geçici ithal yoluyla Türkiye'ye giriş şartları ve bu araçların Türkiye'de kullanılma şartları Geçici İthal Edilen Kara Taşıtlarına İlişkin Gümrük Genel Tebliğinde ayrıntılı olarak düzenlenmiştir.

Karayolları Trafik Kanunu, Kanun Numaras1: 2918, Kabul Tarihi: 13.10.1983, RG 18.10.1983/18195. 
Türkiye'de geçerli sigortaları yoksa bunlar için zorunlu malî sorumluluk sigortası (ZMSS) Türkiye sınırlarına girişte yapılır (m 91/5). Yine Yabancı Plakalı Motorlu Kara Taşıtlarının Ülkemizde İşletilmesinden Kaynaklanan Hukukî Sorumluluk İçin Yaptırılacak Sigortaya İlişkin Usul ve Esaslar Hakkında Yönetmelik'in ${ }^{4} 4$. maddesinde Türkiye'ye girecek yabancı plakalı motorlu kara taşıtlarının işletilmesi sebebiyle üçüncü kişilere verilecek zararlardan kaynaklanan hukukî sorumluluk için zorunlu trafik sigortası veya bu sigorta ile eşdeğer bir sigorta teminatının bulunması zorunluluğu getirilmiştir. Buna göre Türkiye'ye giriş yapan motorlu kara taşıtların işletenlerinin ya Türkiye'de ZMSS yaptırması ya da Türkiye'de ZMSS'ye eş değer yabancı ülkede yaptırılmış bir malî sorumluluk sigortasının bulunması zorunludur.

Bir ülkede hangi sigortaların geçerli olacağı, o ülke hukukuna göre tespit edilir. Hukuk sistemlerinde yurt dışında yaptırılan sigortaların, hangi şartlarda geçerli olabileceğine dair özel hükümler söz konusu olabilmektedir. Örneğin 5684 sayıll Sigortac1lkk Kanunu'nun 15/2. maddesinde, Türkiye'deki yerleşik kişilerin Türkiye' deki sigortalanabilir bazı menfaatlerinin yurt dışında da sigortalanabilmesine imkân tanınmıştır. Türkiye'de yaptırılan ZMSS yalnızca Türkiye sınırları içinde geçerlidir (Karayolları Motorlu Araçlar ZMSS Genel Şartları m A.3). Dolayısı ile yurt dışında da geçerli olması için ayrı bir sigortanın ya da hem ülkede hem ülke dışında geçerliliği olan sigorta sözleşmelerinin yaptırılması gerekir. Kaldı ki ülkeler, yabancı ülkede düzenlenmiş sigorta poliçelerini eşdeğer de kabul etmeyebilir. Bir ülkede düzenlenmiş bir poliçenin diğer ülkede kabul edilmemesi de motorlu kara taşıtlarının milletlerarası kullanımını engelleyebilmektedir.

Yeşil Kart Sisteminin ilk amacı, motorlu taşıtların, uluslararası sınırlardan ${ }^{6}$ uluslararası geçerliliği olan bir sigorta belgesi ile geçişini kolaylaştırmaktır. Böylelikle bu sigortaya sahip bir araç, sınırda ZMSS yaptırmak zorunda kalmayacaktır. Bu sistemin ikinci amacı ise yabancı plakalı araçların gittikleri ülkede karıştıkları kazalardan dolayı zarar görenlerin korunmasıdır. Bu şekilde zarar gören, yabancı plakalı aracın işletilmesinden kaynaklanan zarardan dolayı tüm taleplerini ileri sürebileceği sorumlu bir muhatap bulabilecek ve aracın yabancı plakalı olmasından dolayı ayrıca bir mağduriyet yaşamayacaktır. Yeşil Kart Sigortası, kazanın meydana geldiği ülkedeki asgarî ZMSS limiti kadar koruma sağlamaktadır. Dolayısı ile zarar gören kendi ülkesinde kayıtlı bir aracın kendisine zarar vermesine denk bir korumaya kavuşmuş olmaktadır?.

Yabancı Plakalı Motorlu Kara Taşıtlarının Ülkemizde İşletilmesinden Kaynaklanan Hukukî Sorumluluk İçin Yaptırılacak Sigortaya İlişkin Usul ve Esaslar Hakkında Yönetmelik, RG 13.07.2011/27993.

Sigortacılık Kanunu, Kanun Numarası: 5684, Kabul Tarihi: 03.06.2007, RG 14.06.2007/26552.

Bürolar Konseyinin belirlediği şekle uygun olarak düzenlenmek zorunda olan Yeşil Kartın geçerli olduğu ülkeler, kartın arkasında gösterilmek zorundadır: Hasan Tahsin Gökcan, Karayolları Trafik Kanununa Göre Hukukî Sorumluluk Tazminat Sigorta ve Rücu Davaları (9. Bası, Seçkin 2018) 745.

Robert Merkin and Maggie Hemsworth, The Law of Motor Insurance (2nd edn, Sweet\&Maxwell 2015) 681; Nuray Ekşi, Türk ve Avrupa Birliği Hukukunda Yabancı Unsurlu Sigorta Sözleşmelerinde Uygulanacak Hukuk (Beta İstanbul 2012) 37; Yasemin Tufan, 'Uluslararası Motorlu Araçlar Zorunlu Malî Sorumluluk Sigortası ve Yeşil Kart Sistemi' (2008) Dokuz Eylül Üniversitesi Sosyal Bilimler Enstitüsü, Yayınlanmamış Yüksek Lisans Tezi <tez.yok.gov.tr> Erişimm Tarihi 10 Ağustos 2020 52-53; Gökcan (n 6) 745. 
Yeşil Kart Sistemi, milletlerarası anlaşma seviyesinde de düzenlenmiştir. Avrupa Konseyi tarafindan Motorlu Taşıtlar Zorunlu Malî Sorumluluk Sigortasina İlişkin Avrupa Sözleşmesi (bundan sonra Avrupa Sözleşmesi olarak anılacaktır) hazırlanmış ve 1959 yılında imzaya açılmıştı̊r. Sözleşme 22.09 .1969 yılında yürürlüğe girmiştir. Türkiye, Sözleşmeyi 1974 yılında bazı çekincelerle imzalamış ancak 4477 sayılı uygun bulma Kanunu 1999 tarihinde kabul edilmiştir'. Sözleşmenin amacı başlangıç hükümlerinde, kendi ülkelerinde trafik kazalarında zarar görenlerin haklarının zorunlu bir sigorta sisteminin kurulması yoluyla güvence altına alınması şeklinde ifade edilmiştir. Sözleşmenin bir diğer amacı, âkit devletlerde uluslararası sigorta büroları ile garanti fonlarının kurulması ve işletilmesini desteklemektir. Böylelikle Avrupa Sözleşmesinde Yeşil Kart Sistemine işlerlik kazandırmak için uluslararası büroların kurulması öngörülmüş ve uluslararası sigorta belgeleri, diğer bir ifade ile yeşil kart çıkartmaları öngörülmüştür. Türkiye Motorlu Taşıtlar Bürosu (TMTB), bu Sözleşmede öngörülen büro olarak görev yapmaktadır ${ }^{10}$. Ayrıca Sözleşme'nin 6. maddesinde ZMSS ile ilgili temel ilkeler tespit edilmiş ve mağdura doğrudan sigortacıya başvuru hakkı tanınması kabul edilmiştir.

Yeşil Kart Sisteminin gelişmesini sağlayan bir diğer unsur da Avrupa Birliği düzenlemeleridir ${ }^{11}$. Özellikle zorunlu sigortaya ilişkin Avrupa Birliği yönergeleri, Yeşil Kart Sistemini üye devletler arasında daha da geliştirmiş ve Birlik üyesi ile diğer bazı ülkeler arasında Yeşil Kart ibrazı aranmaksızın seyahat mümkün hâle gelmiştir ${ }^{12}$.

\section{TMTB'nin Kurulması ve Görevleri}

Yeşil Kart Sistemine dâhil olmak amacı ile TMTB, Türkiye Sigorta ve Reasürans Şirketleri Birliği bünyesinde 1963 y1lında tüzel kişiliği haiz "Türkiye Sigorta ve Reasürans Birliği Motorlu Taşıt Bürosu” unvanı altında Ticaret Bakanlığının çıkardığı

\footnotetext{
Avrupa Sözleşmesi hakkında ayrıntılı bilgi için bkz Tufan (n 7) 10 vd.

9 Motorlu Taşıtlar Zorunlu Malî Sorumluluk Sigortasına İlişkin Avrupa Sözleşmesinin Onaylanmasının Uygun Bulunduğuna Dair Kanun: RG 11.11.1999/23873. Avrupa Konseyinin web sayfasında Sözleşmenin Türkiye bakımından 25.07.2000 tarihinde yürürlüğe girdiği bilgisi verilmektedir. <https://www.coe.int/en/web/conventions/full-list/-/conventions/ treaty/029> Erişim Tarihi 13 Ağustos 2020. Sözleşme, sözleşmeyi sonradan onaylayacak bir imzacı devlet tarafından, onay belgesinin tevdi tarihinden itibaren 90 gün sonra yürürlüğe girer (m 15). Sözleşme hakkında ayrıntılı bilgi için bkz Ekşi (n 7) $35 \mathrm{vd}$.

10 Türkiye Motorlu Taşıt Bürosunun Çalışma Usul ve Esasları Hakkında Yönetmelik m 4.

11 Avrupa Birliği düzenlemeleri hakkında ayrıntılı bilgi için bkz Etem Kara, 'Sınırötesi Trafik Kazaları: Avrupa Birliğinde ve Türk Hukukunda Zorunlu Mali Sorumluluk Sigortası’ (2016) 6(11) Hasan Kalyoncu Hukuk Fakültesi Dergisi 219 vd.

12 Yeşil Kart uygulamasında dahi bazı zorlukların yaşanması sebebiyle Yeşil Kart sistemine dâhil Avrupa Birliği ülkeleri ile Andorra, Norveç, İzlanda, Sırbistan, İsviçre ve Lihtenştayn olmak üzere 34 ülke, Avrupa girişimi ile kendi ülkelerinde düzenlenen üçüncü kişi sorumluluk sigortalarının diğer ülkelerde de tanınmasını öngören çok taraflı anlaşma imzalamıştır. Özellikle Çok Taraflı Garanti Sözleșmesi ile yeșil kart ibrazı zorunluluğu kaldırılmıștır. Dolayısı ile artık 34 ülkede Yeșil Kart gerekmeksizin motorlu taşıt ile seyahat mümkün hâle gelmiştir: <https:/www.cobx.org/index.php/article/39/greencard> Erişim Tarihi 13 Ağustos 2020. Günümüzde Yeşil Kartın ibrazı zorunlu ülkeler şunlardır: Türkiye, Azerbaycan, Rusya, Beyaz Rusya, İran, Tunus, Fas, İsrail, Ukrayna, Rusya, Bosna ve Hersek, Arnavutluk, Makedonya, Belarus, Moldova.
} 
bir Yönetmelik ile kurulmuştur' ${ }^{13}$. TMTB’nin kurulmasından sonra Türkiye, Yeşil Kart Sistemine 1 Ocak 1964 tarihinde katılmıştır. Büronun unvanı, 26 Ekim 1991 tarihli ve 21033 sayılı Resmî Gazete' de yayınlanan Türkiye Motorlu Taşıt Bürosunun Çalışma Esas ve Usulleri Hakkında Yönetmelik (bundan sonra Yönetmelik olarak anılacaktır) ile bugünkü hâlini almıştır ${ }^{14}$.

Bürolar Konseyi'nin İç Tüzüğü'nün (Internal Regulation) ${ }^{15}$ 2. maddesinde millî bürolar, "millî sigortacılar bürosu (national insurers' bureau)" adiyla anılmış ve 5 No'lu tavsiye metnine uygun olarak kurulan ve Büro Konseyine üye olan profesyonel bir kurum olarak tanımlanmıştır.

İç Tüzük Kurallarına göre, millî büronun üç şartı haiz olması gerekmektedir. Bunlardan ilki, Büro'nun profesyonel bir kurum olmasıdır. İkincisi, Büro’nun Bürolar Konseyi’ne üye olması; Üçüncüsü ise, Büro'nun 5 No’lu Tavsiye Kararı'ndaki şartları haiz olmasıdır.

5 No'lu Tavsiye Kararında aranan şartlar ise şunlardır:

- Yetkili sigortacılar tarafından kurulan, ilgili ülkenin hükümetince resmî olarak tanınan tek kurum olmalıdır.

- Büroya ancak motorlu taşı1 malî mesuliyet sigortası yapan sigortacılar üye olabilmelidir.

- Motorlu taşıt malî mesuliyet sigortası yapacak sigortacıların büroya üye olması mecburîdir.

- Büronun yükümlülüğünü yerine getirebilmesi için üye sigortacıların finansmanı paylaşma yükümlülüğü olmalıdır ${ }^{16}$.

Büro’nun görevlerinden birisi, uluslararası geçerliliği olan Yeşil Kart Sigortası yapmak ya da yapılmasını sağlamaktır ${ }^{17}$. Büro ya kendisi Yeşil Kart Sigortası yapacak ya da bu yetkiyi anlaşmalı sigorta şirketlerine devredecektir. Büro, Avrupa Sözleşmesi'nde sigortacı tanımının içinde kabul edilmiştir (Avrupa Sözleşmesi m

13 RG 19.10.1963/ 11535. Büronun Yönetmelik ile kuruluşunun eleştirisi için bkz Mahmut Yavaşi, Kara Taşıtları Sigortaları (Yetkin 2020) 187 dpn 414

14 < https://www.tmtb.org.tr/BURO/Tarihce/BuroTarihce\#collapseTwo > Erişim Tarihi 13 Ağustos 2020.

15 Bürolar Konseyinin İç Tüzüğü 30 Mayıs 2002 yılında Yunanistan'ın Girit Adası'nda yapılan Genel Kurul'da kabul edilmiştir ve değişik tarihlerde (2008, 2013, 2016, 2017, 2019) revize edilmiştir: <https://www.cobx.org/sites/default/ files/cob_file_folder/2020-internal-regulations-marrakesh-1-July-2020-clean-version.pdf $>$ Erişim Tarihi 13 Ağustos 2020. Bürolar Konseyinin hazırladığı ve millî bürolar arasında imzalanması gereken model anlaşmada, millî bürolara İç Tüzüğün emredici kurallarına uyma yükümlülügüü getirilmektedir: <https://www.cobx.org/article/46/documents-green-card-pillar > Erişim Tarihi 13 Ağustos 2020.

16 İç Tüzüğü Açıklayıcı Not (Explanatory Memorandum to the Internal Regulations) 7. <https://www.cobx.org/sites/default/ files/cob_file_folder/2020-explanatory-memorandum-marrakesh-1-July-2020-clean-version.pdf $>$ Erişim Tarihi 12 Ağustos 2020.

17 Iş1 Ulaş, Uygulamalı Sigorta Hukuku Mal ve Sorumluluk Sigortaları (Ankara 2010) 845. 
Ek-I m 1). Nitekim İç Tüzükte Büronun yeşil kartın düzenlenmesinden ve tesliminden sorumlu olduğu kabul edilmiştir (İç Tüzük m 7/1). Yönetmelikte TMTB’nin görevleri arasında “...motorlu araçların işletilmesi nedeniyle tabi olunan mali sorumluluğu karşılamak üzere yurtdlşında geçerli sigorta belgelerinin basım, denetim ve düzenlenmesi ile bu sigorta belgeleri kapsamında motorlu araçların sebep olduğu hasarların ödenmesi...” sayılmıştır. Büro sadece kendi ülkesinde kayıtlı taşıtlar için Yeşil Kart verebilir. Bunun haricinde ancak hiçbir büronun bulunmadığı ülkede ikamet eden sigortalılara Yeşil Kart verilmesine de imkân tanınmıştır (İç Tüzük m 7/3). Doktrinde Yeşil Kartı veren Büro, "tazmin eden büro (zahlendes Büro)" olarak anılmaktadir ${ }^{18}$.

Büro'nun görevlerinden bir diğeri de düzenlediği Yeşil Kartlar dolayısıyla yabancı ülkedeki büro tarafından karşılanan zararların tazminlerinden kaynaklı rücu taleplerini karşılamaktır. Bürolar Konseyi İç Tüzüğü’nün 6. maddesinde her büronun, kaza ülkesindeki büronun ya da onun görevlendirdiği acentenin İç Tüzük hükümlerine (m 5) göre ödediği tazminatı garanti ettiği kabul edilmiştir. Yeşil Kartı düzenleyen sigorta şirketi iflâs etmiş olsa dâhi Büro’nun garanti yükümlülüğü devam eder. Ancak Tüzüğe aykırı ödemelerde Büro’nun rücu taleplerini karşılama yükümlülüğü bulunmamaktadır ${ }^{19}$. Bürolar arasında özel hukuka dayalı karşılıklı borç doğuran bir ilişki olduğu ileri sürülmektedir ${ }^{20}$. Sigortacılık Kanunu'na göre Yeşil Kart uygulamaları için faaliyet gösteren TMTB tarafından yapılacak ödemeler için Güvence Hesabına başvurulabilir (m 14/2-d). Nitekim Yönetmelikte TMTB'nin görevleri arasında "[ü]yelerince düzenlenen sigorta belgeleri çerçevesinde üyelerine garantör" olmak da sayılmıştır (Yönetmelik m 5/2-b). Büro rücu kapsamında ödediği tazminatı, şartları varsa zarar verenden talep edebilir.

Ayrıca TMTB, diğer ülkelerde bulunan bürolar ile Bürolar Konseyi’nin hazırladığı "Bürolararası Model Anlaşma"yı imzalayabilir²1 . Bir büro diğer bürolar ülkesi ile ikili anlaşma yapmak zorunda değildir. Ancak ülke büroları arasında ikili anlaşma yapılması, rücu taleplerinin tahsilini kolaylaştırmaktadır²2.

TMTB'nin bir diğer görevi de yabancı bürolar tarafından Yeşil Kart verilmiş yabancı plakalı araçların Türkiye'de üçüncü kişilere verdikleri zararı gidermedeki sorumluluğu ve muhataplığıdır.

\footnotetext{
Tufan (n 7) 55.

19 İç Tüzüğü Açıklayıcı Not 37. Rücu talebinin kaynağının taraflar arasındaki garanti sözleşmesi olduğu hakkında bkz Tufan (n 7) 60.

20 Tufan (n 7) 59.

21 Bkz dpn 13.

22 Martin Metzler, 'Nationales Versicherungsbüro (NVB) \& Nationaler Garantiefonds (NGF)', Haftpflicht des Motorfahrzeughalters - neue Antworten auf alte Fragen (Herausgeber: Fellmann, Walter ), (Stämpfli 2013) 161.
} 


\section{TMTB'nin Türkiye'de Meydana Gelen Kazalardaki Görevleri ve Muhataplığı}

\section{A. Genel Olarak}

TMTB'nin Türkiye'de yerine getirmesi gereken görevler Bürolar Konseyi İç Tüzükte detaylı şekilde tespit edilmiştir. Bunların ilki, Türkiye'de meydana gelen bir kaza ile ilgili tüm soruşturma işlemlerini yürütmektir. Tüzüğe göre Büro, Yeşil Kart ile ilgili bir kaza hakkında bilgilendirildiğinde, resmî bir talep gerekmeksizin kazanın oluş şeklini araştırır. Ayrıca mümkün olan en kısa süre içinde Yeşil Kartı düzenleyen sigorta şirketi ya da ilgili büroyu bilgilendirir. Eğer yabancı sigorta şirketinin ülkede bir muhabiri varsa ona da bildirim yapılması gerekir (İç Tüzük m 3/1).

Yeşil Kart sistemine dâhil olan sigorta şirketlerinin potansiyel kaza ülkelerinde, kendi adlarına ödeme yapmaya yetkili birer muhabir bulundurduğu ve uygulamada ödeme işlemlerinin çoğu zaman ülke bürolarının müdahalesi olmadan bu muhabirler arac1lığı ile yürütüldüğü belirtilmektedir ${ }^{23}$.

İkincisi, meydana gelen zararı ZMSS şartları ve limitleri çerçevesinde kusur esasına göre tazmin etmektir (İç Tüzük m 3/4). Büronun özel bir anlaşması bulunması ya da yabancı sigorta şirketinin kaza yerindeki zorunlu malî mesuliyet sigortasından daha geniş teminatlar vermesi hâlinde limit aşan ödemeler yapılabilir ${ }^{24}$. KTK'nın 92/1-f maddesi uyarınca Türkiye'de manevî tazminat, ZMSS'nin sağladığı teminatın dışındadır. Hâlbuki bazı yabancı sigorta şirketleri, manevi tazminatı da teminat kapsamında kabul edebilir. Bu hâlde TMTB manevî tazminatın ödenmesinden sorumlu olduğu gibi, manevî tazminat konusunda anlaşma da yapabilir. Konu hakkında Yargıtay'ın bir kararı şu şekildedir:

“Davalı vekili, müvekkilinin yabancı plakalı araçların Türkiye’de yaptığı kazalarda sebep olduğu zararlar için kusur ve limite göre, limit üstü ve trafik sigortası şartları dışındaki talepler için ancak yabanct...şirketinin ihtiyaren teminat vermesi halinde sorumlu olduğunu, somut olayda aracın yeşil kart sigortacısının yabancı şirket olduğunu, ihtiyaren verdiği teminatta manevi tazminatı da üstlendiğinin bildirildiğini, davacı torunların doğdukları yere bakılınca muris büyükanneleri ile eylemli ve gerçek bir bağlllık ilişkisinin mümkün olmadığını, tek taraflı kazada sürücünün murisin oğlu, davacıların ise amcası olduğunu,

\footnotetext{
Bkz Metzler (n 22) 161. Söz konusu muhabirler, faaliyetlerini Yeşil Kart sisteminin yürütülmesine hasretmiş değildir. Zira, Avrupa Birliği'nin Karayolları Malî Sorumluluk Sigortalarına ilişkin 2009/103 sayılı Motorlu Taşıt Sorumluluk Sigortası ve Sigorta Yükümlülüğünün Kontrolüne ilişkin Avrupa Parlamentosu ve Konseyi Yönergesi m. 21 hükmü gereğince Birlik içinde kara motorlu taşıtları için sorumluluk sigortası yapan tüm sigortacıların tüm üye devletlerde ilgili üye devlette yerleşik olan ve zarar gören tarafın tazminat talebinde bulunabileceği bir hasar temsilcisi (claim representative/Der Schadensregulierungsbeuaftragter) ataması gerekmektedir. Buna ek olarak, aynı Yönergenin m 24 ve m 25 hükümleri gereğince, her üye devletin başka bir üye devlette gerçekleşen kazalardan doğan maddî ve cismanî zararları tazmin etmekle görevli bir kurumu oluşturması veya yetkilendirmesi gerekmektedir. Bkz Dirk Looschelders, 'Internationale Zuständigkeit für Klagen gegen ausländische Entschädigungsstellen und Grüne-Karte-Büros' (2018) 38(4) IPRax (Praxis des Internationalen Privat- und Verfahrensrechts) 361.

24 TMTB'nin yurt dışında karşılamak zorunda olduğu teminatların daha yüksek olması sebebiyle diğer devletler ile limit aşan anlaşmalar yapmasının Türkiye’nin lehine olduğu ifade edilmektedir. Tufan (n 7) 79 dpn 253.
} 
amcalarına açamadıkları davayı müvekkiline karşı açtıklarını beyanla davanın reddini savunmuştur. Dosya içeriğinden yabancı plakalı araç ile davacının boşadı̆̆ eşi Kl'in idaresinde bulunan aracın karlştığı trafik kazası sonucu Kl'in öldüğ̈̈, yabancı plakalı aracın sigorta şirketi tarafindan davacı K2'a ödenmek üzere manevi tazminat belirlendiği, ancak davacı ile ölen $K 1$ 'in boşanmış olduğu ve ölenin başkası ile evli olduğunun anlaşılması üzerine ödemenin yapılmadiğı anlaşılmıştır. Dava yabancı plakalı aracın sigorta şirketi tarafindan belirlenen manevi tazminatın Türkiye Motorlu Taşıt Bürosu'ndan tahsili istemine ilişkindir"'25.

Büro, başka bir ülke hukukunu yetkili kılan kanunlar ihtilâfı kuralları dâhil kaza ülkesinde geçerli olan hukukun yorumlanmasında ve ihtilâfın çözümünde münhasıran yetkilidir. Ancak Yeşil Kartı düzenleyen sigorta şirketinin ya da büronun açık talebi varsa nihaî bir karar vermeden önce ilgililere bilgi vermelidir (İç Tüzük m 3/4). TMTB'nin zorunlu malî sigorta limitini aşan talepler konusunda anlaşma yapabilmesi için Yeşil Kartı düzenleyen sigorta şirketine danışmalı ve onayını almalıdır (İç Tüzük $\mathrm{m} \mathrm{3/5).}$

Zorunlu malî sorumluluk sigortası esas olarak üçüncü kişilere verilen zararları kapsadığından İç Tüzüğe göre ödenmesi gereken zararlar, özellikle kusurlu olduğu durumlarda yabancı aracın sürücüsü ya da haleflerinin ${ }^{26}$ uğradığı zararları kapsamamaktadır ${ }^{27}$. Bu sınırlama, uygulanacak hukuka göre kusurlu olsa bile araç sürücüsünün de zarar gören üçüncü kişi kabul edilmesinden dolayı işletenin sorumlu olduğu durumlar ile ilgili değildir ${ }^{28}$.

\section{B. TMTB'nin Sorumluluğunun Hukukî Dayanakları}

TMTB'nin yetkileri ve sorumluluğu hakkında hem milletlerarası düzenlemelerde hem de iç hukukumuzda bazı kurallar yer almaktadır. Avrupa Sözleşmesinde, doğrudan olmasa da dolaylı olarak TMTB'nin sorumluluğuna dair bazı kurallara yer verilmiştir. Yargıtay kararlarında da Avrupa Sözleşmesine atıf yapılmaktadır ${ }^{29}$.

Avrupa Sözleşmesinde sigortacı terimi tanımlanmış ve bu tanımın içine millî bürolar da dâhil edilmiştir. Tanım şu şekildedir:

25 Yargıtay 17 HD, 4807/1491, 17.03.2009 (Lexpera İçtihat Bankası).

26 Türk hukukunda da araç işletenin izniyle aracı kullanan kişi, üçüncü kişi durumunda olmadığı gibi kazayı bizzat gerçekleştiren kişi olduğundan dolayı kendisinin ya da ölümü halinde yakınlarının ZMSS kapsamında tazminat hakları bulunmamaktadır. Ancak Yargıtay'ın aksi yönde kararları bulunmaktadır. Türk hukukunda Yargıtay Hukuk Genel Kurulunun 17-787/92, 22.02.2012 sayılı ilâmı ile "davacıların ölenin salt mirasçıları sıfatıyla değil, destekten yoksun kalan 3. Kişi sifatıyla dava açtıklarl, ölüm nedeniyle doğrudan davacılar üzerinde doğan destekten yoksunluk zararının oluşumundaki kusurun davacılara yansıtılamayacă̆ğ” gerekçesiyle aracın kullanıcısının mirasçıları da üçüncü kişi kapsamında zarar gören olarak değerlendirilmiştir. Ayrıntılı bilgi için bkz Atilla Altop, 'Trafik Kazaları Sebebiyle İleri Sürülen Destekten Yoksun Kalma Taleplerine İlişkin Yargıtay Hukuk Genel Kurulu'nun 15.06.2011 Tarihli E. 2011/17-142 K. 2011/411 Sayılı ve 22.02.2012 Tarihli E. 2011/17-787 K. 2012/92 Sayılı Kararları ile Yargıtay 17. Hukuk Dairesi'nin 05.06.2012 Tarihli ve E. 2011/11551 K. 2012/7391 Sayılı Kararının Değerlendirilmesi' (2008) 8(1) Yaşar Üniversitesi Dergisi 151 vd. Daha sonra Karayolları Trafik Kanunu'nun 92. maddesinde 2016 yılında 6704 sayılı Kanunun 4. maddesi ile yapılan açık bir düzenleme ile bu uygulamaya kanun ile son verilmiştir. RG 26.04.2016/29695. Yargıtay Hukuk Genel Kurulu da 1315/1239, 01.11.2017 sayılı ilâmı ile önceki içtihadından dönmüştür. Ayrıntılı bilgi için bkz Mustafa Çeker, 6102 Sayılı Türk Ticaret Kanununa Göre Sigorta Hukuku (20. Bası, Karahan Kitabevi 2019) 270.

27 İç Tüzüğü Açıklayıcı Not, 14.

28 İç Tüzüğü Açıklayıcı Not, 14.

29 Yargıtay 17 HD, 7060/7063, 20.6.2017 (Lexpera İçtihat Bankası). 
"Sigortacl" teriminden: İkinci maddenin birinci paragrafi uyarınca hükümet tarafindan tanınmışs sigorta şirketi ve aynı maddenin ikinci paragrafina göre genellikle ülke dışında kayıtlı taşıtların ulusal topraklar üzerinde neden oldukları zararların tazmini ile yükümlü Büro anlaşılır” (Ek I m 1).

Tanım gereği millî bürolar da sigortacı kabul edilmiştir. Yeşil Kartı düzenleyen ya da düzenlenmesini sağlayan büro "tazmin eden büro (zahlendes Büro)", kazanın meydana geldiği ülkedeki büro ise "işlemi yapan büro (behandelndes Büro)" olarak anılmaktadir ${ }^{30}$.

Sözleşme'nin 8. maddesinde konu hakkında daha açık bir hüküm bulunmaktadır.

“Âkit Taraflar, uluslararası sigorta belgeleri çıkaracak ve ek hükümlerin ikinci maddesinin ikinci paragrafinda öngörülen zararları tazmin edecek büroların kuruluş ve işleyişini teşvik edeceklerdir" (m 8).

Sözleşmenin bu maddesi ile âkit devletlere, zararı tazmin edecek millî bürolar kurma yükümlülüğü getirilmiştir. $\mathrm{Bu}$ maddede sözü geçen Ek Hükümlerdeki düzenleme ise şu şekildedir:

"Bununla birlikte, genellikle ülke dışında kayıtlı taşıtlar, hükümetçe yetki verilen bir Büronun, bu taşıtların neden olduğu hasarlardan zarar gören kişilerin yerel kanuna göre tazmin edilmesi yükümlülüğ̈̈nü üzerine alması koşuluyla, ülke topraklarında kullanılabilir" (Ek Hükümler 2. Madde ve İkinci Paragraf).

Sözleşmenin bu hükmüne göre yabancı plakalı araçların üçüncü kişilere verdiği zararın ülkede kurulmuş bir büro aracılığı ile tazmin edilmesi gerekmektedir. Sözleşmenin hazırlandığı dönemde Yeşil Kart Sistemi yürürlükte idi. Dolayısı ile bu maddede Yeşil Kart Sistemine göre kurulan büroların kastedildiğini ifade etmek yanlış olmayacaktır.

İkinci olarak Bürolar Konseyi İç Tüzük Başlangıç hükümlerinde, üye devletlerde kurulacak millî büroların, yabancı plakalı aracın kendi ülkelerinde üçüncü kişilere verdiği zararları tazmin etme işlevinin olacağı açıkça ifade edilmiştir (Başlangıç Hükümleri, m 4/c).

Bürolar Konseyi İç Tüzüğünün 3/3. maddesine göre de büro herhangi bir talebi, dostane şekilde çözme veya tazminat ödemesini ihtiva eden herhangi bir adlî veya mahkeme dışı bir çözüm sürecini takip etme yetkisini haizdir. Bu düzenleme uyarınca bürolar, diğer ülkelerdeki bürolar ile anlaşmalar yapmak suretiyle birbirlerine talepleri dostane bir şekilde çözme, mahkeme dişı çözüm yöntemleri veya adlî süreç ile ihtilâfı sona erdirme yetkilerini vermektedir. Büroların yetkisi, anlaşma yapmak, yapılan teklifleri reddetmek ve ödeme yapmayı içerecek kadar geniştir ${ }^{31}$.

\footnotetext{
Tufan (n 7) 55.

31 İç Tüzüğü Açıklayıcı Not, 14.
} 
Büronun yetkisi iki açıdan sınırlandırılmıştır. Birincisi, Yeşil Kartı veren sigortacının veya uygunsa ilgili büronun, İç Tüzüğe göre çıkarlarının en iyi şekilde korunmasıdır ${ }^{32}$. Büro, adına ödeme yaptığı sigortacının veya büronun vekili konumdadır. Sisteme dâhil olmak için Bürolar Konseyince hazırlanan model anlaşmalar millî bürolar tarafindan imzalanmakta ve bu model anlaşmalar üzerinden taraflar arasında vekâlet ilişkisi kurulmuş olabilmektedir. Kazanın meydana geldiği ülke bürosu, yeşil kartı düzenleyen büro adına tüm hasar ve tazmin işlemlerini kendi ülkesi hukukuna uygun olarak yürütmeyi üstlenmiş olmakta; bunun karşllı̆ında da Yeşil Kartı düzenleyen büro, işlemi yapan büronun söz konusu ilişkinin bir gereği olarak yöneltilebileceği tüm talepleri karşılamayı taahhüt etmiş olmaktadır ${ }^{33}$. Dolayısıyla işlemi yapan büronun, vekâlet ilişkisi gereği özen yükümlülüğüne ${ }^{34}$ uygun hareket etmesi gerekir. Aksi hâlde, tazmin eden büronun tahkime gitme hakkı bulunmaktadır (İç Tüzük m 19). İkinci sınırlama ise kaza ülkesinde yürürlükte olan zorunlu malî sorumluluk sigortasının emredici şartlarıdır ${ }^{35}$. Söz konusu vekalet ilişkisi ise doğrudan değil, dolaylı temsil yetkisi ihtiva eder. Bir diğer ifadeyle taleple muhatap kılınan Büro kendi adına ve fakat işlemi (sigorta sözleşmesini) gerçekleştiren büro hesabına ödemeyi gerçekleştirir. Yeşil Kart sahibi araç işleteninin zarar verdiği üçüncü şahıs, yabancı sigorta şirketini değil TMTB'yi muhatap olarak görür ve zararının tazminini ondan talep eder. Bu Büro üçüncü şahsın tazminat talebini karşıladıktan sonra, hesabına ödeme yaptığı yabancı sigorta şirketine ${ }^{36}$ başvurur ve yaptığ ödemenin kendisine ödenmesini talep eder.

Mülga 7397 sayılı Sigorta Murakabe Kanunu m 38/5'de, konu ile ilgili doğrudan bir hüküm bulunmakta idi. Kanun metni şu şekilde idi:

"Yurt dışında sigortalanmış bulunan ve yerel bürolarca geçerli sigorta sertifikalarını taşıyan motorlu kara taşıt araçları tarafindan Türkiye'de neden olunan hasarların tespiti, Türkiye Motorlu Taşıt Bürosu eksperleri tarafindan yapılır. Bu hasarların tedvir ve tesviyesi; Türkiye'de geçerli Zorunlu Mali Sorumluluk Sigortası limitlerine kadar, münhasıran Türkiye Motorlu Taşıt Bürosu'na aittir."

Sigortacılık Kanunu'nda ise konuya ilişkin doğrudan bir hüküm bulunmamaktadır. Ancak Sigortacılık Kanunu'nun 14/2. maddesinde TMTB'nin de Güvence Hesabına başvurabileceği düzenlenmiştir. Kanun metni şu şekildedir:

\footnotetext{
İç Tüzüğü Açıklayıcı Not, 14.

Tufan (n 7) 122

6098 sayı1ı Türk Borçlar Kanunu'nun 506/2. maddesine göre vekil, üstlendiği iş ve hizmetleri, vekâlet verenin haklı menfaatlerini gözeterek, sadakat ve özenle yürütmekle yükümlüdür.

35 İç Tüzüğü Açıklayıcı Not, 14.

36 Yukarıda açıklandığı gibi Yeşil Kartı düzenleyen yabancı sigorta şirketleri, üçüncü şahısların uğradığı zararları bizzat karşılamak üzere, potansiyel kaza riskinin bulunduğunu düşündüğü ülkelerde özel temsilcilik de açmış olabilir. Bu gibi durumlarda, zarar gören üçüncü şahıslar taleplerini, doğrudan Yeşil Kart sigortasını düzenleyen yabancı sigorta şirketine de yöneltme imkânına sahip olabilirler.
} 
"Hesaba;

d) Yeşil Kart Sigortası uygulamaları için faaliyet gösteren Türkiye Motorlu Taşıt Bürosunca yapılacak ödemeler için, başvurulabilir."

Yönetmelikte, TMTB'nin görevine ilişkin aşağıdaki şekilde bir düzenleme bulunmaktadir:

“...motorlu araçların işletilmesi nedeniyle tabi olunan mali sorumluluğu karşılamak üzere yurtdlşında düzenlenen ve ilgili mevzuat uyarınca ülkemizde geçerli bulunan sigorta sözleşmeleri kapsamında bu araçların sebep olduğu hasarların tedvir ve tasfiyesini temin eder" (m 5).

Yargıtay kararlarında TMTB’nin sorumluluğuna ilişkin özellikle Yönetmeliğin 5. maddesine sıcça atıf yapılmaktadır.

“Türkiye ...Bürosunun Çalışma Usul ve Esasları Hakkında Yönetmelik 2. bölüm 5. maddesinde 'Büro, 4477 sayılı Kanun ile onaylanması uygun bulunan Motorlu Taşıtlar Zorunlu Mali Sorumluluk Sigortasına İlişkin Avrupa Sözleşmesi başta olmak üzere, motorlu araçların işletilmesi nedeniyle tabi olunan mali sorumluluğu karşılamak üzere yurtdışında geçerli sigorta belgelerinin basım, denetim ve düzenlenmesi ile bu sigorta belgeleri kapsaminda motorlu araçların sebep olduğu hasarların ödenmesini ve motorlu araçların işletilmesi nedeniyle tabi olunan mali sorumluluğu karşılamak üzere yurtdlşında düzenlenen ve ilgili mevzuat uyarınca ülkemizde geçerli bulunan sigorta sözleşmeleri kapsamında bu araçların sebep olduğu hasarların tedvir ve tasfiyesini temin eder.' düzenlemesi getirilmiştir"'37.

Güvence Hesabı Yönetmeliği’nin 9 ve 11. maddelerinde de yabancı plakalı araçların sebebiyet verdiği zararların tazmininin Güvence Hesabı'nın sorumluluğunda olduğuna ilişkin hükümler yer almaktadır. Bu hükümlere aşağıda yer verilmiştir:

"Ayrıca Hesaba, Yeşil Kart Sigortası kapsamında Türkiye sinırları içinde meydana gelen zararlardan dolayı Büroca tekemmül ettirilen hasar dosyalarının tazminat ödemesi için Büro tarafindan da başvurulabilir" (m 9/2).

"Yeşil Kart Sigortası kapsamında Türkiye sinırları içinde zarara uğrayan kişiler için büro tarafindan tekemmül ettirilen hasar dosyaları çerçevesinde intikal ettirilen tazminat tutarları hesap tarafindan ödenir" (m 11/1).

\section{TMTB'ye Karşı Dava Açılması}

Yeşil Kart ile Türkiye'de bulunan yabancı plakalı bir aracın üçüncü kişilere zarar vermesi durumunda, genel hükümler uyarınca, zarar görenin, yabancı plakalı aracın işletenine veya sigortacısına müracaat etmesi mümkündür. Aynı şekilde sigortacı sayılan ve Yeşil Kartın verilmesini sağlayan büroya karşı da husumet yöneltilmesi

\footnotetext{
37 Yargıtay 17 HD, 20484/2753, 27.02.2014 (Lexpera İçtihat Bankası). Aynı yönde Yargıtay kararları için bkz Yargıtay 17 HD, 15698/5046, 3.4.2014; Yargitay 17 HD, 7060/7063, 20.6.2017; Yargitay 17 HD, 3670/938, 26.02.2009 (Lexpera İçtihat Bankas1).
} 
mümkündür. Ancak kazanın meydana geldiği ülkedeki zarar görenleri ${ }^{38}$ yabancı ülkedeki sigorta şirketleri ya da büroya muhatap kılmak, yabancı plakalı araç ile mağduriyet yaşayan kimseleri ikinci defa mağdur etmek anlamını taşır. İşte Yeşil Kart Sistemi, aynen yerli bir aracın zarar verdiği üçüncü kişilerin durumuna eşdeğer şekilde, zarar gören kişilerin haklarına çabuk ve kolay bir şekilde ulaşmasını sağlamak üzere kazanın meydana geldiği ülkedeki büronun, zarar görenler karşısında bir muhatap olarak yer almasını sağlamak amacıyla kurulmuştur ${ }^{39}$. ZMSS kapsamında kalan bütün talepler için yabancı sigorta şirketi ya da büro yerine kazanın meydana geldiği ülkedeki büroya başvurulabilir. Ancak kazaya sebebiyet veren kişilerin, işletenlerin, ZMSS kapsamında yabancı büro ya da sigorta şirketlerinin sorumluluğu da devam etmektedir.

Bu tür talepler karşısında TMTB'nin muhataplığının hukukî niteliğini de izah etmek gerekir. Yeşil Kart Sigortası ile Türkiye'ye gelen yabancı plakalı araçların, Türkiye'de sebebiyet verdikleri kazalardan dolayı doğrudan TMTB'ye müracaat edilmesi durumunda TMTB, yabancı sigorta şirketi veya büronun, acentesi olarak mı yoksa söz konusu zararın tazminden bizzat sorumlu olduğu için mi yer aldığının, Bürolar arasındaki ilişki de dikkate alınarak izah edilmesi gerekir. Çünkü bazı Yargıtay kararlarında TMTB'ye yabancı şirkete izafeten dava açıldığından bahsedilmektedir. Mesela bu türden bir kararda "davanın yeşil kart sigortacısına izafeten davalı Büro'ya açılması gerektiği düşünülse bile dava dilekçesi içeriği dikkate alındı̆̆ında bu durumun esasen temsilde hata olduğunun kabul gerekir. O halde, davalı Büro hakkındaki davanın husumet nedeniyle reddi doğru değildir" "40 cümlesine yer verilmiştir. Keza başka bir kararında yine Yargıtay: "Yabancı plakalı araçların Türkiye'de karıştıkları kazalarda şayet geçerli bir yeşil kart sigortaları mevcutsa, yeşil kart sigortacılarına izafeten kusur esasına göre kaza tarihindeki sigorta limitleri dâhilinde sebebiyet verilen zararlar davalı Motorlu Taşıt Bürosu tarafindan karşılanacaktır" ${ }^{\prime 1}$ yönünde hüküm tesis etmiştir.

Bir başka Yargıtay kararında da “Davalı Türkiye Motorlu Taşıtlar Bürosu'nun sorumluluğu, Z.M.S.S. genel şartlart çerçevesinde, yabancı K3 sigorta şirketine izafeten ve sürücülerin kusuru oranında, kaza tarihindeki trafik sigortası limitleri dâhilindedir" 42 cümlesi yer almaktadir.

\footnotetext{
Zarar görenin kazanın meydana geldiği ülkenin vatandaşı olması ya da o ülkede ikamet etmesi şart değildir. Looschelders (n 23) 361 .

39 Alman doktrininde, Yeşil Kart sisteminin Almanya bakımından özel bir önemi haiz olduğu, zira Almanya'da yaşayan Türk asıllı kișilerin sorumluluğunu Almanya'da yerleșik sigortacılara sigorta ettirdikleri araçlarla Türkiye'de karıștıkları trafik kazalarından doğan zararların tazminine ilişkin taleplerin Yeşil Kart Sistemi sayesinde daha kolay bir şekilde halledilebildiği ifade edilmektedir. Bkz Christian Armbrüster, Privatversicherungsrecht (2. Aufl, Mohr Siebeck 2019) 564. Yine bu kapsamda Yeşil Kart Bürosunun, ziyaret edilen ülkenin hukukuna uygun olarak zarar görene tazminat ödemeyi garanti ettiği kabul edilmektedir: Junker, Abbo, Münchener Kommentar zum Bürgerlichen Gesetzbuch (Hrsg.: Säcker, F. Jürgen/ Rixecker, Roland/ Oetker, Hartmut/ Limperg, Bettina), Band 13 8. Aufl. Beck 2021, Rom II-VO Art. 18 Randnummer 19.

40 Yargıtay 11 HD, 11073/13833, 05.11.2007 (Lexpera İçtihat Bankası).

41 Yargitay 11 HD, 406/2326, 28.02.2008 (Lexpera İçtihat Bankas1).

42 Yargitay 17 HD, 4932/816, 25.02.2008 (Lexpera İçtihat Bankas1).
} 
Yukarıda, bürolar arasında, büroların kendi adlarına ve fakat yeşil kart sigorta poliçesini tanzim eden büro hesabına işlemler yapma yetkisinin bulunduğu ve aralarında bir vekâlet ilişkisinin mevcut olduğu ifade edilmiştir. Zira izah edildiği üzere imzalanan model anlaşmalar ile uymayı taahhüt ettikleri Bürolar Konseyi'nin İç Tüzük Kurallarına göre, bürolar aslında birbirlerini işlerini karşılıklı olarak görmekle yükümlü kılmış olmaktadırlar. Nitekim kazanın meydana geldiği ülkedeki büro yabancı büro adına kazadan mütevellit "hasarların tedvir ve tasfiyesi" işini yapmakta; işin görülmesinden sonra da aralarında mevcut olduğu kabul edilen iç ilişki çerçevesinde ilgili yabancı büroya rücu etmiş olmaktadır.

Bürolar Konseyi İç Tüzügünün 3/3. maddesinde bürolara uyuşmazlığ1 çözme, tazminat ödemesi yapma, sulh olma ve her türlü adlî süreci takip etme yetkisi verilmiştir. Bu hükümler dikkate alındığında TMTB'nin, dolaylı temsil yetkisi bulunan vekil konumunda olduğu ifade edilmelidir. $\mathrm{Bu}$ durumda dolaylı temsilci olan büro zarar gören kişilerin doğrudan muhatabı konumunda olacaktır. Zira dolaylı temsil ilişkisinin niteliği gereği temsilci, kendi adına ve fakat temsilcisi olduğu kişi hesabına hareket ettiğinden, zarar gören karşısında muhatap yalnızca TMTB olacaktır. Bununla beraber, bürolar arasındaki iç ilişki kapsamında varlığı kabul edilen vekâlet ilişkisinin ve bu ilişkinin bir sonucu olan dolaylı temsil yetkisinin zarar görenin Türkiye'deki Büroya yönelttiği taleplerin hukukî temelini izah etmeye bir katkısı olmadığı açıktır. Zira bu ilişki ancak vekâlet ilişkisinin tarafları arasındaki rücu ilişkisi bakımından bir anlam ve işlevi olan bir ilişkidir.

Zarar gören kişilerin, sigorta sözleşmesinin tarafı olmayan ve fakat tarafiyla vekâlet ilişkisi bulunan Büro'ya yönelttiği davaların hukukî dayanağı, yukarıda ayrıntısıyla izah edilen Yeşil Kart sisteminin usul ve esaslarını tayin eden kanun hükümleridir. Bir diğer ifadeyle Türkiye'deki büro, zarar görenlere karşı kanun gereği sorumlu kabul edilmiştir; onun sorumluluğu (aynı ZMMS yapan sigorta şirketinin durumunda olduğu gibi) kanundan kaynaklanan bir sorumluluktur.

TMTB'nin, yabanc1 sigorta şirketi ya da bürosunun acentesi ${ }^{43}$ sifatılla davada yer almasının düşünülüp düşünülemeyeceği üzerinde de durulmalıdır. Uygulamada acenteye karşı açılan davalarda "izafeten" ibaresi kullanılmaktadır ${ }^{44}$. Kanuna göre, acenteler, aracılıkta bulunduğu veya akdettiği sözleşmelerden dolayı sigorta şirketi adına dava açabileceği gibi acenteye karşı aynı sıfatla dava da açılabilir (TTK m $105 / 2)^{45}$. Acente kanunî temsilcisi olarak davada müvekkilini temsil eder ${ }^{46}$.

\footnotetext{
Acente sözleşmesi hakkında ayrıntılı bilgi için bkz Hüseyin Ülgen, Mehmet Helvacı, Arslan Kaya ve N. Füsun Nomer Ertan, Ticari İşletme Hukuku (Vedat 2019) 830; Reha Poroy ve Hamdi Yasaman, Ticari Işsletme Hukuku (Vedat 2019) 297 vd; Sabih Arkan, Ticari İşletme Hukuku (25. Bası, Banka ve Ticaret Hukuku Araştırma Enstitüsü 2019) 216 vd.

44 “Acente fiilen aracıllkta bulunduğu veya bizzat müvekkili nam ve hesabın akdettiği sözleşmelerden doğan uyuşmazlıklarda müvekkili adına dava açabileceği gibi....kendisine karşı da aynı sıfatla ve fakat müvekkiline izafeten dava açabilir": Ülgen, Helvac1, Kaya ve Nomer Ertan, (n 43) 845.

45 Ülgen, Helvacı, Kaya ve Nomer Ertan, (n 43) 845; Arkan, (n 43) 237.

46 Kanunî temsil bazı şartlara bağlanmıştır. Şartlar hakkında ayrıntılı bilgi için bkz Ülgen, Helvacı, Kaya ve Nomer Ertan, (n 43) $845 \mathrm{vd}$.
} 
"Ancak, davacı tarafindan icra takibine itiraz edilmesi üzerine C. bayraklı geminin donatanına izafeten ve kendisine asaleten B.a karşı işbu dava açılmış olup yargılama sırasında davalı B. 'in söz konusu geminin donatanı olmadı̆̆ını savunması üzerine donatana izafeten acentesi $\boldsymbol{Y}$. Deniz Acenteliği A.Ş'ye dava dilekçesi tebliğ edilmiş ve adı geçen şirket de bu sıfatla yargılamaya katılmıştır" ${ }^{\prime 4}$.

6102 sayılı Türk Ticaret Kanunu'nun ${ }^{48}$ 102/1. maddesinde acente tanımlanmıştır:

"Ticari mümessil, ticari vekil, satış memuru veya işletmenin çalışanı gibi işletmeye bağlı bir hukuki konuma sahip olmaksızın, bir sözleşmeye dayanarak, belirli bir yer veya bölge içinde sürekli olarak ticari bir işletmeyi ilgilendiren sözleşmelerde aracılı etmeyi veya bunları o tacir adına yapmay meslek edinen kimseye acente denir."

TMTB, yabancı sigorta şirketi adına sözleşme yapılmasına aracılık eden ya da bizzat bunlar adına hukukî işlemlere taraf olan kişi konumunda değildir. Kaldı ki acentenin müvekkilin borçlarından dolayı sorumluluğu da bulunmamaktadır. Acentelerin ad ve hesabına hareket ettikleri kişilere karşı Türkiye'de açılacak olan davalar sonucunda alınan kararlar, acentelere karşı uygulanamaz (TTK m 105/3). Dolayısı ile maddî hukuk bakımından hak sahibi ve usûl hukuku anlamında sıfatı (husumet ehliyetini) haiz olan acente değildir; acentelik veren kişidir (müvekkildir) ${ }^{49}$. Hâlbuki TMTB'ye karşı açılan davalarda hüküm bizatihi TMTB aleyhine verilmekte ve ilâm TMTB'ye karşı icra edilebilmektedir. Dolayısı ile TMTB Türkiye'deki davalarda yabancı sigortacının veya yabancı Büronun acentesi konumunda da değildir.

TMTB'nin sorumluluğu, Güvence Hesabının sorumluluğuna ${ }^{50}$ da benzetilebilir. Güvence Hesabının sorumluluğu, mağdurun Güvence Hesabının sorumluluğu kapsamına $^{51}$ giren zararının, zorunlu sigortalardan karşılanamaması hâlinde Kanun gereği ortaya çıkmaktadır (Sigortacılık Kanunu m 14). Zorunlu sigortaları düzenleyen Sigortacılık Kanununun 13. maddesi gereğince zorunlu sigortalara ilişkin olarak Kanunda belirlenen koşulların ${ }^{52}$ oluşması halinde ortaya çıkan zararların, bu sigortalarla saptanan geçerli teminat miktarlarına kadar karşılanması amacıyla Türkiye Sigorta ve Reasürans Şirketleri Birliği nezdinde Güvence Hesabı oluşturulması Sigortacılık Kanunu'nun 14. maddesinde hükme bağlanmıştır ${ }^{53}$.

\footnotetext{
47 Yargitay 11 HD,12256/9394, 17.9.2015 (Lexpera İçtihat Bankası).

48 Türk Ticaret Kanunu, Kanun Numarası: 6102, Kabul Tarihi: 13.01.2011, RG 14.02.2011/27846.

49 Ülgen, Helvacı, Kaya ve Nomer Ertan, (n 43) 845; Poroy ve Yasaman, (n 43) 305; Rıza Ayhan, Hayrettin Çağlar ve Mehmet Özdamar, Sigorta Hukuku Ders Kitabı (3. Bası, Yetkin 2020) 77.

50 Güvence Hesabının kurulmasının amaçları hakkında ayrıntılı bilgi için bkz Tekin Memiş, 'Güvence Hesabının Taşımanın 100 km. Altında Olması Nedeniyle Zorunlu Koltuk Ferdi Kaza Sigortası Kapsamında Ödeme Yapmayı Reddetmesi Hukuka Uygun mudur?' (2012) 3(1) İnönü Üniversitesi Hukuk Fakültesi Dergisi 137-138.

51 Güvence Hesabının sorumluluğunun kapsamı hakkında bkz Vural Seven, 'Sigorta Güvence Hesabı'nın Kapsamı ve Destekten Yoksun Kalma Tazminatı' (2017) 12(157-158) Bahçeșehir Üniversitesi Hukuk Fakültesi Dergisi 31 vd. Memiş, (n 50) $139 \mathrm{vd}$

52 Güvence Hesabına başvuru şartları hakkında ayrıntılı bilgi için bkz Seven, (n 51) 35 vd. Ayhan, Çağlar ve Özdamar, (n 49) $109 \mathrm{vd}$.

53 Ayhan, Çağlar ve Özdamar, (n 49) 110.
} 
Güvence Hesabının sorumluluğu, esas olarak işletenin sorumluluğuna ${ }^{54}$ dayanmaktadır. 2918 sayılı Karayolları Trafik Kanunu'nun 91. maddesinde açıkça işletenlerin, aynı Kanunun 85. maddesinde düzenlenen sorumluluklarının karşılanması amacıyla ZMSS yaptırmaları gerektiği ifade edilmiştir ${ }^{55}$. Güvence Hesab1, mağdurun Kanun kapsamındaki zararından işletenin zorunlu sigortacısı gibi sorumlu kabul edilmektedir.

TMTB ile zarar gören veya işleten arasında herhangi bir akdî ilişki bulunmamaktadır. Nitekim bir Alman mahkemesi, Polonya'da meydana gelen kazadan dolay1 hem Alman Yeşil Kart Bürosuna hem de Polonya Yeşil Kart Bürosuna karşı Almanya’da açılan bir davada, kazanın meydana geldiği ülkedeki Yeşil Kart bürosunun zarar görenle hiçbir akdî ilişki içinde olmadığını, sadece ilgili sorumluluk sigortacısı hesabına zararın tasfiyesine aracılık eden bir kuruluş olduğunu ifade ederek Polonya Yeşil Kart Bürosu bakımından Alman mahkemelerinin milletlerarası yetkisinin olmadığına karar vermiştir ${ }^{56}$.

TMTB, Yeşil Kart Sigortası ile Türkiye'ye gelen yabancı plakalı araçların verdikleri zarardan asgarî, Türkiye'deki ZMSS kapsamında bizzat sorumludur. Diğer bir ifade ile bir önceki başlıkta ayrıntısıyla yer verilmiş olan hukukî dayanaklar ${ }^{57}$, maddî hukuk bakımından TMTB'yi hak sahibine karşı sorumlu kılmaktadır. Bu yaklaşım, sorumluluk sigortalarının genel mahiyetine de uygundur. Sorumluluk sigortalarında sigortalının zarar verdiği kişi taleplerini, kanun gereği doğrudan sigortacıya yöneltebilir (TTK m 1429). Zarar görenin doğrudan dava hakkı olarak anılan bu hukukî imkân, yabancı araçların karıştığı kazalar bakımından Yeşil Kart Sistemi sayesinde desteklenmiş olmaktadır. Böylece zarar gören kişi, doğrudan Büro’ya yönelteceği talepleriyle sorumluluk sigortacısına yöneltme imkânını haiz olduğu giderim talebini daha etkili bir şekilde kullanma imkânı elde etmiş olacaktır ${ }^{58}$; ki bu Yeşil Kart Sistemi’nin temel gayesidir.

Taraf sıfatı, dava konusu kılınan sübjektif hakla davanın tarafları arasındaki ilişkiyi ifade eder. Sıfat, davada davacı ve davalı olarak gösterilmiş kişilerin dava konusu hak ile gerçekten ilgili, diğer bir ifade ile hak sahibi ya da yükümlüsü olup

54 85. maddesine göre, motorlu araç işletilmesi sebebiyle verilen zarardan işleten kusursuz sorumluluk esasına göre sorumludur (KTK m 85/1): Fikret Eren, Borçlar Hukuku Genel Hükümler (22. Bası, Yetkin 2017) 690.

55 Şaban Kayıhan, 'Zorunlu Mali Mesuliyet Sigortasında (ZMSS=Trafik Sigortası) Sigorta Ettirenin Kendi Tam Kusuru ile Vefatı Halinde Mirasçıların Üçüncü Kişi Sıfatıyla Müteveffanın Sigortacısına Başvurmaları Durumuna İlişkin Hukuki Düşünceler' (2016) 22(1) Marmara Üniversitesi Hukuk Fakültesi Hukuk Araştırmaları Dergisi 255.

56 Landgericht Darmstadt, 13.10.2016, 3 O 349/14.

57 Hukukî dayanaklar olarak, Motorlu Taşıtlar Zorunlu Malî Sorumluluk Sigortasına İlişkin Avrupa Sözleşmesi, Sigortacılık Kanunu (m 14/2), Yabancı Plakalı Motorlu Kara Taşıtlarının Ülkemizde İşletilmesinden Kaynaklanan Hukukî Sorumluluk İçin Yaptırılacak Sigortaya İlişkin Usul ve Esaslar Hakkında Yönetmelik, Güven Hesabı Yönetmeliği ve Bürolar Konseyi İç Tüzüğü sayılabilir. Ayrıntılı bilgi için bkz III, B.

58 Bu noktada özellikle belirtmek gerekir ki, Yeşil Kart Sistemi ile zararın tazmini amacıyla doğrudan TMTB'ye başvuru imkânının getirilmiş olması, yabancı plakalı araçların Türkiye'de işletilme halinde iken sebebiyet verdiği zararlara ilişkin genel sorumluluk sistemini ortadan kaldırmış olmamaktadır. Bir diğer ifadeyle yabancı plakalı aracın işleteni de KTK m 85 hükmü çerçevesinde, bu zararın tazmininden sorumlu olmaya ve kalmaya devam edecektir (MÖHUK m 34). 
olmadıklarıyla ilgili olup maddî hukuk kuralları gereğince belirlenir ${ }^{59}$. Taraf sıfatı, maddî hukuk bakımından, dava konusuna ilişkin olarak kimin hak sahibi olduğunu veya sorumlu olduğunu ifade eder. Bunun için de davanın esasına girilmesi gerekir. Yukarıda açıklandığı gibi maddî hukuk kuralları, zarar görenlere karşı TMTB’nin doğrudan sorumluluğu kuralını getirmiştir. TMTB davacı olduğunda hak sahibi, davalı olduğunda ise yükümlü olup olmadığı, davanın esasına uygulanan maddî hukuk kurallarına göre belirlenecektir.

O hâlde TMTB, yabancı bürolar tarafından verilmiş Yeşil Kart Sigortası ile Türkiye'ye gelen yabancı plakalı araçların üçüncü kişilere verdiği zararlardan dolayı asgarî olarak Türkiye'deki ZMSS kapsamında "bizzat" sorumludur" ${ }^{60}$. Üstelik burada yabancı sigorta şirketi ve işletenin ve zarar verenin de kanundan doğan müteselsil sorumluluğu bulunmaktadır. Burada TBK m 61 gereğince birden çok kişinin aynı zarardan çeşitli sebeplerden dolayı sorumlu olması durumu vardır. TMTB'nin yanında yabancı büro poliçeyi düzenleyen ya da düzenlenmesine yetki veren sigortacı sıfatıyla sözleşmeden doğan sorumluluğu, aracın işletenin Karayolları Trafik Kanunu m 85 uyarınca tehlike sorumluluğu, aracı kullananın ise TBK m 49 uyarınca kusur sorumluluğu söz konusudur ${ }^{61}$. Dolayısı ile TMTB'ye karşı dava açılmasında "izafeten” gibi ifadelerin kullanılması doğru olmasa gerektir. Nitekim Yargıtay da birçok kararında TMTB ile yeşil kart sigortasının tarafı sigorta şirketinin müteselsilen sorumlu olduğu yönünde hüküm tesis etmiştir ${ }^{62}$.

\section{TMTB’ye Karşı Açılacak Davalarda Türk Mahkemelerinin Milletlerarası Yetkisi ve Uygulanacak Hukuk}

Trafik kazasından kaynaklanan davalarda zarar verenin hukukî sorumluluğu haksız fiil hükümlerinden kaynaklanmaktadır. Dolayısı ile zarar görenin, zarar verene ve sigorta şirketine karşı açacağı davalarda Türk mahkemelerinin milletlerarası yetkisi ve uygulanacak hukuk, haksız fiil hükümlerine göre belirlenir.

Türk mahkemelerinin milletlerarası yetkisi, özel bir yetki kuralı olmadıkça iç hukukun milletlerarası yetki kuralları itibarıyla tayin edilir (MÖHUK m 40) ${ }^{63}$. Yeşil Kartlı bir aracın Türkiye'de karıştığı trafik kazasından dolayı üçüncü kişinin zarar

\footnotetext{
Süha Tanrıver, Medenî Usûl Hukuku Cilt I Temel Kavramlar ve İlk Derece Yargılaması (Yetkin 2016) 512; Baki Kuru, Medenî Usûl Hukuku Ders Kitabı (Legal 2015) 94; Hakan Pekcanıtez, Medenî Usûl Hukuku Cilt I (Editörler: Pekcanitez H, Özekes M, Akkan M ve Taş Korkmaz H) (15. Bası, On İki Levha 2017) 548 vd; Murat Atalı, İbrahim Ermenek ve Ersin Erdoğan, Medeni Usul Hukuku Ders Kitabl (2. Bası, Yetkin 2019) 227-229.

60 Kara (n 11) 233; Gökcan (n 6) 745.

${ }_{61}$ Birden çok kişinin aynı zararın tazmininden sorumlu olması halinde tabi olacaklar esaslar hakkında bkz. Eren, Genel Hükümler (n 54) 839 .

62 Bu yönde kararlar için bkz. Yargıtay 17 HD, 18007/7784, 19.6.2019; Yargıtay 17 HD, 18790/9728, 21.10.2019; Yargıtay 17 HD, 3670/938, 26.02.2009 (Lexpera İçtihat Bankası).

63 Türk mahkemelerinin milletlerarası yetkisi için bkz Ergin Nomer, Devletler Hususî Hukuku (22. Bası, Beta 2017) 460 vd; Vahit Doğan, Milletlerarası Özel Hukuku ( 6. Bası, Savas 2020) 60 vd; Aysel Çelikel ve B. Bahadır Erdem, Milletlerarası Özel Hukuk (15. Bası, Beta 2017) 543 vd; Cemal Şanlı, Emre Esen ve İnci Ataman Figanmeşe, Milletlerarası Özel Hukuk (7. Bas1, Beta 2019) 383 vd.
} 
görmesi, yabancı araç kullanan kişinin haksız fiil sorumluluğunu gündeme getirir. 5718 sayılı Milletlerarası Özel Hukuk ve Usul Hukuku Hakkında Kanun'da ${ }^{64}$ özel bir yetki kuralı bulunmadığı için, haksız fiilden doğan ihtilâflarda Türk mahkemelerinin milletlerarası yetkisi, iç hukukun yer itibarı ile yetki kurallarına göre belirlenir.

Haksız fiilden doğan davalarda, haksız fiilin işlendiği veya zararın meydana geldiği yahut gelme ihtimâlinin bulunduğu yer yahut zarar görenin yerleşim yeri mahkemesi yetkilidir (HMK m 16). Ayrıca genel yetkili mahkeme de olan davalının yerleşim yerinde de dava açılabilir (m 6/1).

Bu hükümler dikkate alındığında TMTB'ye karşı açılacak davalarda, davacının (zarar görenin) yerleşim yeri mahkemesi, kazanın meydana geldiği yer mahkemesi, kaza yeri ile zarar yeri farklı ise zararın meydana geldiği yer mahkemesi ve TMTB'nin yerleşim yerinin bulunduğu İstanbul Mahkemeleri, milletlerarası yetkiyi haizdir.

MÖHUK'ta haksız fiillere ilişkin genel hüküm, MÖHUK m 34'de yer almaktadır. Buna göre haksız fiilden doğan ihtilâflar, haksız fiilin işlendiği yer hukukuna tâbidir. Türkiye'de Yeşil Kartlı bir aracın karıştığı kazada, haksız fiilin işlendiği yer olarak Türk hukuku uygulanır (MÖHUK m 34/1). Maddî ve fiilî olmak koşulu ile zarar haksız fiilin gerçekleştiği başka bir ülkede ortaya çıkmış ise, zararın meydana geldiği ülke hukuku uygulanır (MÖHUK m 34/2) ) $^{65}$. Türkiye'de meydana gelen trafik kazalarında bu durumun gerçekleşme ihtimali azdir ${ }^{66}$. Bu kapsamda konuya ilişkin bir kararında Yargitay:

"Davalı F3 Sigorta A.Ş.nin temyiz itirazlarına gelince, dava, haksı fiilden kaynaklanan tazminatın, zarara neden olan 3. kişilerden rücuen tahsili istemine ilişkindir. Mahkemece her ne kadar 2675 sayıl MÖHUK'nun 25/2.b maddesi uyarınca olaya Avusturya Hukuku'nun uygulanacă̆ı gerekçesiyle yazılı şekilde hüküm kurulmuşsa da, aynı yasa maddesinin 1. fikrası uyarınca haksız fiilden doğan borçlar, haksız fiilin işlendiği yer hukukuna tabidir. Olay yeri Sulusaray/Yeşilyurt olduğuna ve davacı sigortalısı bu kazada vefat ettiğine göre, davacının hak sahiplerine ödemelerini Avusturya'da yaptığı gerekçesiyle, zararın meydana geldiği ülkenin Avusturya olduğu kabul etmek mümkün değildir. Dolaylstyla, uyuşmazlığa Türk" hukukunun uygulanması yönünde hüküm tesis etmiştir ${ }^{67}$.

Eğer haksız fiilden doğan borç ilişkisi başka bir ülke ile daha sıkı ilişkili ise sıkı ilişkili ülke hukuku uygulanır (MÖHUK m 34/3). Sıkı ilişkinin tespitinde, tarafların vatandaşlığı, ikametgâhları, mutad meskenleri, kazaya karışan araçların kayıt yerleri gibi kriterler dikkate alınabilir ${ }^{68}$. Taraflar haksız fiilin meydana gelmesinden sonra açık olarak hukuk seçimi de yapabilirler (MÖHUK m 34/5).

\footnotetext{
${ }^{64}$ Milletlerarası Özel Hukuk ve Usul Hukuku Hakkında Kanun, Kanun Numarası: 5718, Kabul Tarihi: 27.11.2007, RG 12.12.2007/26728.

65 Nomer (n 63) $361 \mathrm{vd.}$

${ }_{66}$ Fiil yeri ile zarar yerinin farklı ülkelerde olmasına dair örnekler için bkz Doğan (n 63) 438 vd; Çelikel ve Erdem (n 63 ) 447.

67 Yargitay 11 HD, 5829/2562, 21.03.2005 (Lexpera İçtihat Bankasi).

68 Şanl1, Esen ve Ataman Figanmeşe (n 63) 326; Nomer (n 63) 365; Doğan (n 63) 439.
} 
TMTB'ye karşı açılan davalarda Yargıtay uygulanacak hukuka dair bir değerlendirmede bulunmadan doğrudan Türk hukukunu uygulamaktadır. Hâlbuki kazaya karışan aracın yabancı plakalı olması ve ZMSS'nın da yabancı bir sigorta şirketi tarafindan yapılması sebebiyle, söz konusu kaza ve ihtilâf yabancı unsurludur ${ }^{69}$. Kazanın Türkiye'de meydana gelmesinden dolayı bu uygulamanın MÖHUK m 34/1'e uygun olduğu söylenebilir; ancak diğer ihtimâllerin dikkate alınmaması sebebiyle eleştiri konusu da yapılabilir.

Haksız fiile uygulanacak hukuk, haksız fiil sorumluluğunun koşullarını, kapsamını, neticelerini, kusuru ve kusurun derecelerini, hukuka aykırılık unsurunu, illiyet bağını, tazminatın türünü ve miktarını tayin edecektir ${ }^{70}$. Yargitay bir kararında TMTB'ye karşı dava açılıp açılamayacağını sigorta poliçesine uygulanacak hukuka (MÖHUK m 24) göre tespit edilmesine karar vermiştir. Buna göre ilgili kararda Yargitay:

“...Bu durumda, uyuşmazliğın çözümünde belirleyici unsur olan merkezi Almanya'da ki davalı sigorta şirketinin düzenlediği sigorta poliçesi ile verilen sigorta güvencesinin kapsamı ve niteliğinin ne olduğu net ve kesin bir açıklıkta saptanması gerekmektedir.

Bu bakımdan, MÖHUK'un 24 ncü maddesindeki düzenleme de dikkate alınarak, söz konusu poliçenin asl, özel-genel şartları ile tüm eklerinin özgün metinleri ile buna ilişkin Alman yasalart ve varsa diğer mevzuatın getirtilip, Türkçe tercümeleri yapıldıktan sonra poliçenin kapsamı ve niteliği ile teminatın ne olduğunun, iddia ve savunmalar göz önüne alınarak, Türkiye Motorlu Taşıt Bürosu'na izafeten davanın açılıp açılamayacağının sigorta uygulamacısı ve sigorta hukuku öğretim üyelerinden oluşturulacak-tercihen Almanca'ya ve Alman Sigorta Hukuku'na vakıf-bilirkişi kurulundan rapor alındiktan sonra, oluşacak sonuca göre bir karar verilmesi gerekirken, eksik incelemeye dayalı yazılı şekilde hüküm tesisi doğru olmamıs, kararın bu nedenle bozulması gerekmiştir"'71.

Kanaatimizce Yargitay'ın bu kararı yerinde değildir. Öncelikle Yeşil Kartlı bir araçta bulunan yolcuların ZMSS kapsamında olup olmadığı, haksız fiil esaslarına tâbidir $^{72}$. Özellikle ZMSS şartları, limitleri, kapsamı münhasıran kaza yeri hukukuna tâbidir. Yeşil Kart Sisteminde, söz konusu sorumluluk sigortası sözleşmesi esasen ödeme bürosunun bulunduğu devletin hukukuna tâbi iken, sözleşme ile ifası kararlaştırılan hukukî korumanın kapsamı, kazanın meydana geldiği ve işlemi yapan büronun bulunduğu devletin hukukuna tâbidir ${ }^{73}$. Bu bakımdan işlem yapan büronun bulunduğu devlet hukuku hem mağdurun istifade edebileceği asgarî ZMSS limiti hem de tazminatın ödenmemesi halinde başvurulabilecek hukukî yollar hakkında belirleyicidir $^{74}$.

69 Doktrinde, kazaya karışan aracın Yeşil Kart Sistemine dâhil olması sebebiyle yabancı unsurlu bir olayın, iç hukuku ilgilendiren bir mesele hâline geldiği ifade edilmektedir. Bkz Metzler (n 22) 160.

70 Şanlı, Esen ve Ataman Figanmeşe (n 63) 326; Nomer (n 63) 362; Doğan (n 63) 441.

71 Yargitay 11 HD, 7645/10526, 10.07.2007 (Lexpera İçtihat Bankas1).

72 Türk hukukunda ZMSS sigortasına konu araçta bulunan yolcuların, zarar gören üçüncü kişi olarak sigortacıya müracaat haklarının olduğu kabul edilmektedir: Ayrıntılı bilgi için bkz Çeker (n 40) 272-273.

73 Wulf-Henning Roth, Internationales Versicherungsvertragsrecht (Paul Siebeck 1985) 614-615.

74 Junker, (n 39) Rn. 25. 
Örneğin, yabancı sigorta poliçesinde ve yabancı sigorta poliçesinin tâbi olduğu hukuka göre hatır yolcusu olsun ya da olmasin, Türk hukukunun aksine zarar gören üçüncü kişi kabul edilmemekte ise kazaya karışan yabancı araçta bulunan bu yolcular, yabanc1 sigortaciya veya TMTB'ye müracaat edemeyecek midir? Kanaatimizce bu sorunun cevabı kaza yeri hukukuna göre verilmelidir. Yukarıda izah edilen hükümlerden de anlaşılacağı üzere TMTB kaza yerinde geçerli olan ZMSS kapsamında sorumludur. Kaldı ki doktrinde zorunlu sigortaya ilişkin düzenlemelerin doğrudan uygulanan kural oldukları ileri sürülmektedir ${ }^{75}$.

Yabanc1 sigorta poliçesinin tâbi olduğu hukuk, ancak Türkiye'de geçerli ZMSS limitleri ve kapsamını aşan zararlar bakımından uygulanabilir. Diğer bir ifade ile Türkiye'de geçerli ZMSS limitini ve kapsamını aşan zararın, yabancı sigortacıdan talep edilip edilemeyeceği, sigorta sözleşmesinin tâbi olduğu hukuka göre tespit edilebilir kanaatindeyiz.

MÖHUK m 34/4'de, haksız fiile veya sigorta sözleşmesine uygulanacak hukukun imkân vermesi hâlinde zarar görenin, talebini doğrudan doğruya sorumlunun sigortacısına karşı ileri sürebileceği kabul edilmiştir. Uygulanacak hukukun Türk hukuku olması hâlinde, TTK m 1478 gereği zarar görenin doğrudan TMTB'ye müracaat hakk1 vardır ${ }^{76}$.

\section{Sonuç}

Yabancı plakalı bir motorlu kara taşıtının Türkiye'ye giriş yaparken ya ZMSS yaptırması ya da kendi ülkesinde Türkiye'de de geçerli bir Yeşil Kart Sigortası yaptırması gerekmektedir. Türkiye'nin de dâhil olduğu Yeşil Kart Sisteminin iki amacı bulunmaktadır. Yeşil Kart Sisteminin ilk amacı, üye ülkelerde geçerliliği olan tek tip bir ZMSS sigorta kartı ile motorlu kara taşıtlarının uluslararası hareketliliğini kolaylaştırmaktır. İkinci amaç ise, Yeşil Kart Sigortası ile yabancı plakalı bir aracın karıştı̆̆ı kazalardan dolayı mağdurun, ZMSS limitleri dâhilinde kaza ülkesinde başvurabileceği bir merciin bulunmasıdır. İşte hem Türkiye dışına gidecek araçlara Yeşil Kart Sigortası verilmesini sağlamak hem de Yeşil Kart Sigortalı yabancı plakalı bir aracın Türkiye'de üçüncü kişilere verdiği zararın tazmini amacıyla görevli TMTB kurulmuştur.

TMTB'nin görevleri çalışma esas ve usullerini düzenleyen Yönetmelikte sayılmıştır. Öncelikle TMTB kendi yetkisi dâhilinde verilen Yeşil Kart Sigortasından

\footnotetext{
5 Hatice Kocasakal, Doğrudan Uygulanan Kurallar ve Sözleşmeler Üzerindeki Etkileri (Galatasaray Üniversitesi 2001) 163164. Ancak Roma I Tüzüğü'nün 7/4. maddesinde zorunlu sigortaya ilişkin hükümler doğrudan uygulanan kural olarak kabul edilmemiştir: Ekşi, (n 7) 51-52. Avrupa Birliğinde zorunlu sigortalara, zorunlu sigorta yaptırma yükümlülüğü getiren ülkenin hukukunun uygulanması kabul edilmiştir. Konu hakkında ayrıntılı bilgi için bkz Sedat Sirmen, 'Zarar Sigortaları Kapsamına Giren Sigorta Akitlerinden Doğan Kanunlar İhtilâfı' (2006) Ankara Üniversitesi Sosyal Bilimler Enstitüsü, Yayınlanmamış Doktora Tezi <tez.yok.gov.tr> Erişim Tarihi 10 Ağustos 2020, 71 vd.

76 Ayrıntılı bilgi için bkz Ayhan, Çağlar ve Özdamar (n 49) 324 vd.
} 
dolayı kazanın meydana geldiği yabancı ülkede geçerli ZMSS limitleri ve şartları dâhilinde, üçüncü kişilere o ülke bürosu tarafından ödenen zararları rücuan tazmin edilmesini sağlamak görevi vardır. Yine TMTB, yabancı bürolar tarafından verilmiş Yeşil Kart Sigortası ile Türkiye'de bulunan araçların karıştıkları kazalardan doğan zararların tasfiye ve tedviri ile sorumludur. TMTB bu işlemi yabancı büro adına vekâleten yürütmektedir. Dolayısı ile TMTB vekâlet sözleşmesinde müvekkilin özen borcu çerçevesinde yabancı büronun menfaatlerini gözeterek bu yükümlülügünü yerine getirmelidir. Adına işlem yapılan yabancı büro, Türkiye'de geçerli olan ZMSS limitlerinin üzerinde teminat vermesi hâlinde, TMTB Türkiye'deki ZMSS limitleri üzerinde ödeme de yapabilir. Ödeme yapan büro kazanın meydana geldiği ülkedeki kanunlar ihtilâfı kuralları dâhil, yürürlükte olan hukukun yorumlanmasında ve ihtilâfın çözümünde münhasıran yetkilidir.

Gerek Avrupa Sözleşmesi gibi milletlerarası düzenlemelerde gerek Sigortacılık Kanunu ve TMTB'nin çalışma usûl ve esaslarını düzenleyen Yönetmelik gibi iç hukuk düzenlemelerinde, TMTB'nin Yeşil Kart Sigortası kapsamında Türkiye'de meydana gelen kazalardan dolayı üçüncü kişilere karşı sorumlu olduğu kabul edilmiştir. Bundan dolayı doğrudan TMTB'ye başvurulabilir ve dava açılabilir. TMTB davada, Yeşil Kart Sigortasını yapan sigorta şirketi ya da ilgili büronun vekili ya da acentesi konumunda değildir. Bilâkis maddî hukuk kuralları gereğince zarar görenlere karşı doğrudan sorumludur ve dolayısı ile davada taraf sıfatı vardır. Üstelik TMTB'nin yanında yabancı sigorta şirketi ya da ilgili yabancı Büro da müştereken ve müteselsilen sorumludur. Nitekim bundan dolayı uygulamada, davalar doğrudan TMTB'ye karşı açılmakta ve karar da TMTB'ye karşı icra edilmektedir.

TMTB'ye karşı açılacak davalarda Türk mahkemelerinin milletlerarası yetkisi iç hukukun yer itibarı ile yetki kurallarına göre tespit edilir. TMTB'ye karşı genel yetkili mahkeme olan TMTB'nin yerleşim yerinin bulunduğu yer mahkemesinde dava açılabileceği gibi haksız fiilin işlendiği ya da zararın meydana geldiği yahut zarar görenin yerleşim yeri mahkemesinde de dava açılabilir. TMTB'nin sorumluluğu ve kapsamı, haksız fiillere uygulanacak hukuk kapsamında haksız fiil statüsüne tâbidir. TMTB'nin sorumluluğu genellikle kazanın ve zararın meydana geldiği Türk hukukuna tâbi olacaktır.

\footnotetext{
Hakem Değerlendirmesi: Dış bağımsız.

Çıkar Çatışması: Yazar çıkar çatışması bildirmemiştir.

Finansal Destek: Yazar bu çalışma için finansal destek almadığını beyan etmiştir.

Peer-review: Externally peer-reviewed.

Conflict of Interest: The author has no conflict of interest to declare.

Grant Support: The author declared that this study has received no financial support.
} 


\section{Bibliyografya/Bibliography}

Altop A, 'Trafik Kazaları Sebebiyle İleri Sürülen Destekten Yoksun Kalma Taleplerine İlişkin Yargitay Hukuk Genel Kurulu'nun 15.06.2011 Tarihli E. 2011/17-142 K. 2011/411 Sayılı ve 22.02.2012 Tarihli E. 2011/17-787 K. 2012/92 Sayılı Kararları ile Yargitay 17. Hukuk Dairesi’nin 05.06.2012 Tarihli ve E. 2011/11551 K. 2012/7391 Sayılı Kararının Değerlendirilmesi’ (2008) 8(1) Yaşar Üniversitesi Dergisi 151-184.

Arkan S, Ticari İşletme Hukuku, (Banka ve Ticaret Hukuku Araştırma Enstitüsü 2019).

Armbrüster C, Privatversicherungsrecht (2. Aufl, Mohr Siebeck 2019).

Atalı M, Ermenek İ ve Erdoğan E, Medeni Usul Hukuku Ders Kitabı (2. Bası, Yetkin 2019).

Ayhan R, Çağlar H ve Özdamar M, Sigorta Hukuku Ders Kitabı (3. Bası, Yetkin 2020).

Çeker M, 6102 Sayılı Türk Ticaret Kanununa Göre Sigorta Hukuku (20. Bası, Karahan Kitabevi 2019).

Çelikel A ve Erdem BB, Milletlerarası Özel Hukuk (15. Bası, Beta 2017).

Doğan V, Milletlerarası Özel Hukuku (6. Bası, Savaş 2020).

Ekşi N, Türk ve Avrupa Birliği Hukukunda Yabancı Unsurlu Sigorta Sözleşmelerinde Uygulanacak Hukuk (Beta İstanbul 2012).

Eren F, Borçlar Hukuku Genel Hükümler (22. Bas1, Yetkin 2017).

Gökcan HT, Karayolları Trafik Kanununa Göre Hukukî Sorumluluk Tazminat Sigorta ve Rücu Davaları (9. Bas1, Seçkin 2018).

Junker Abbo, Münchener Kommentar zum Bürgerlichen Gesetzbuch (Herausgeber: Säcker, F. Jürgen/ Rixecker, Roland/ Oetker, Hartmut/Limperg, Bettina Hrsg.) (8. Aufl. Band 13, 2021).

Kara E, 'Sınırötesi Trafik Kazaları: Avrupa Birliğinde ve Türk Hukukunda Zorunlu Mali Sorumluluk Sigortas1' (2016) 6(11) Hasan Kalyoncu Hukuk Fakültesi Dergisi 215-256.

Kayıhan Ş, 'Zorunlu Mali Mesuliyet Sigortasında (ZMSS=Trafik Sigortası) Sigorta Ettirenin Kendi Tam Kusuru ile Vefatı Halinde Mirasçıların Üçüncü Kişi Sıfatıyla Müteveffanın Sigortacısına Başvurmaları Durumuna İlişkin Hukuki Düşünceler' (2016) 22(1) Marmara Üniversitesi Hukuk Fakültesi Hukuk Araştırmaları Dergisi 251-264.

Kocasakal H, Doğrudan Uygulanan Kurallar ve Sözleşmeler Üzerindeki Etkileri (Galatasaray Üniversitesi 2001).

Kuru B, Medenî Usûl Hukuku Ders Kitabı (Legal 2015).

Looschelders D, 'Internationale Zuständigkeit für Klagen gegen ausländische Entschädigungsstellen und Grüne-Karte-Büros’ (2018) 38(4) IPRax (Praxis des Internationalen Privat- und Verfahrensrechts) 360-363.

Merkin R and Hemsworth M, The Law of Motor Insurance (2nd Edition, Sweet\&Maxwell 2015).

Metzler M, 'Nationales Versicherungsbüro (NVB) \& Nationaler Garantiefonds (NGF)', Haftpflicht des Motorfahrzeughalters - neue Antworten auf alte Fragen (Herausgeber: Walter Fellmann), ( Stämpfli 2013) 155-188.

Memiş T, 'Güvence Hesabının Taşımanın 100 km. Altında Olması Nedeniyle Zorunlu Koltuk Ferdi Kaza Sigortası Kapsamında Ödeme Yapmayı Reddetmesi Hukuka Uygun mudur?' (2012) 3(1) İnönü Üniversitesi Hukuk Fakültesi Dergisi 129-150.

Nomer E, Devletler Hususî Hukuku (22. Bas1, Beta 2017).

Pekcanıtez H, Pekcanıtez Medenî Usûl Hukuku Cilt I (Editörler: Pekcanıtez H, Özekes M, Akkan $\mathrm{M}$ ve Taş Korkmaz H) (15. Bası, On İki Levha 2017). 
Poroy R ve Yasaman H, Ticari İsletme Hukuku (Vedat 2019).

Roth, WH, Internationales Versicherungsvertragsrecht (Paul Siebeck 1985).

Seven V, 'Sigorta Güvence Hesabı'nın Kapsamı ve Destekten Yoksun Kalma Tazminatı' (2017) 12(157-158) Bahçeşehir Üniversitesi Hukuk Fakültesi Dergisi 31-62.

Sirmen S, 'Zarar Sigortaları Kapsamına Giren Sigorta Akitlerinden Doğan Kanunlar İhtilâfı' (2006) Ankara Üniversitesi Sosyal Bilimler Enstitüsü, Yayınlanmamış Doktora Tezi <tez.yok.gov.tr> Erişim Tarihi 10 Ağustos 2020.

Şanlı C, Esen E ve Ataman Figanmeşe İ, Milletlerarası Özel Hukuk (7. Bası, Beta 2019).

Tanrıver S, Medenî Usûl Hukuku Cilt I Temel Kavramlar ve İlk Derece Yargılaması (Yetkin, 2016).

Tufan Y, 'Uluslararası Motorlu Araçlar Zorunlu Malî Sorumluluk Sigortası ve Yeşil Kart Sistemi' (2008) Dokuz Eylül Üniversitesi Sosyal Bilimler Enstitüsü, Yayınlanmamış Yüksek Lisans Tezi <tez.yok.gov.tr> Erişim Tarihi 10 Ağustos 2020.

Ulaş I, Uygulamalı Sigorta Hukuku Mal ve Sorumluluk Sigortaları (7. Bas1, Turhan Kitabevi 2010).

Ülgen H, Helvacı M, Kaya A ve Nomer Ertan NF, Ticari Işletme Hukuku (Vedat 2019).

Yavaşi M, Kara Taşıtları Sigortaları (Yetkin 2020). 